\title{
抗酸化能をもつ糖質系食品素材の製造方法の開発
}

\author{
三輪章志 ${ }^{1, \dagger}$ ，中村恵美 ${ }^{1}$ ，小林昭一 ${ }^{2}$ \\ 1 石川県農業総合研究センター, ${ }^{2}$ 社団法人菓子・食品新素材技術センター
}

\section{Development of a Method for Producing a Carbohydrate-Based Food Ingredients with Antioxidant Capacity}

\author{
Shoji MIWA $^{1, \dagger}$, Megumi NAKAMURA ${ }^{1}$, and Shoichi KOBAYASHI ${ }^{2}$ \\ ${ }^{1}$ Department of Natural Resources and Food Processing Ishikawa Agricultural Research Center, \\ 295-1 Bo, Saida, Kanazawa 920-3198, Japan \\ ${ }^{2}$ Japan Confectionery and Innovative Food Ingredients Research Center, 1-18-7 Iriya, Taito-ku, Tokyo 110-8687, Japan
}

\begin{abstract}
We describe a method for imparting corn starch with antioxidant activity by roasting it with tartaric acid. Carbohydrate-based food ingredients produced by this method were called ANOX sugars. Because of this method, raw food materials used in the production of carbohydrate-based food ingredients have high antioxidant activity in addition to quality, color, and flavor. Different temperatures and durations for roasting with varying amounts of tartaric acid were investigated to obtain the optimal conditions for the production of carbohydrate-based food ingredients derived from corn and rice. This production method confirmed that antioxidant activity increased with roasting temperature. The highest antioxidant activity $(28.75 \mu \mathrm{mol}$ trolox $/ \mathrm{g})$ was obtained when $5 \mathrm{~g}$ of tartaric acid was added to $100 \mathrm{~g}$ of carbohydrate-based food ingredient, followed by roasting at $200^{\circ} \mathrm{C}$ for 180 minutes. ANOX sugars have high antioxidant activity, acidity, and color, and can be used as food ingredients.
\end{abstract}

Keywords: antioxidant, carbohydrate -based food ingredients, tartaric acid, roasting

1. 緒言

米やトゥモロコシの粉は，製菓，パン，麺，プレミッ クス，冷凍食品など幅広い分野で利用されている。近 年の健康志向の高まりから玄米粉やトウモロコシの外 皮も含めて粉砕したホミニー，コーングリッツを利用 した加工食品の商品化も増えている.

米やトウモロコシの主成分であるデンプンは，水を 加えて加熱することで糊化して多様な物性を得ること ができる。この特性は，デンプンの原料となる植物に よって多少異なるが，幅広い食品の食感を調整するた めの原料として利用されている．また，デンプンの生 理活性機能は，アミロース含量の高いデンプンでは, 難消化性成分の含量が高いため難消化性デンプンやレ ジスタントスターチとして認知されつつあり，代表的

(受付 2011 年 3 月 24 日, 受理 2011 年 6 月 13 日)

1 ₹ 920-3198 石川県金沢市才田町戊 295-1

2 T 110-0013 東京都台東区入谷 1-18-7

† Fax: 076-257-1683, E-mail: s-miwa@pref.ishikawa.lg.jp
なものとして，ハイアミロースコーンを原料に製造さ れているハイアミロースコーンスターチがある [1,2]. 最近では，難消化性デンプンを含む米品種も開発され， 血糖值の上昇抑制や脂肪蓄積抑制の効果が動物試験に より確認されている [3].

さらに，米に含まれる機能性成分は，主に糠部分に 含まれるビタミン $\mathrm{E}$ やオリザノール，フェルラ酸など が知られている [4-6]. 一方，トウモロコシもビタミン $\mathrm{E}$ を含んでいることが知られている $[7,8]$. また，米， トウモロコシともに，特異な品種としてアントシアニ ン， $\beta$-カロチン，タンニンなどの抗酸化性を示す色素 成分を含む有色品種がある [9-11].

しかし，これら抗酸化成分の含有量はごく微量であ り，米などはそのほとんどが，通常廃棄される糠部分 に多く含まれる。そのため，米やトウモロコシの粉さ らに，それら穀物から抽出したデンプンに扎ては， 抗酸化成分の効果が期待できない.

一方で，農水畜産物を原料として生産される加工食 品は，その加熱工程や保存中の酸化ないし過酸化反応 により酸敗をうけやすいので酸化防止剤が使用されて 
いる．従来使用されてきたブチルヒドロキシトルエン やブチルヒドロキシアニソールなどの合成抗酸化剂は, 発がん性の疑いがある [12]。このため，ビタミン $\mathrm{E}$, ルチン，フェルラ酸など天然物由来の抗酸化剂の利用 が注目されている。しかし，これらも抗酸化活性，利 便性及び安全性の全てを満足するものではない $[12$, 13].

そこで，加工食品の製造において主たる加工原料と して幅広く利用されている米粉およびデンプンなどの 糖質系食品素材を加熱処理などの簡便な処理で抗酸化 能を付与できれば，加工食品の製造時の加熱工程や貯 蔵時における脂質酸化や変色などを防止することがで き，加工食品の品質向上や賞味期限の延長などの効果 が期待できる。これにより，加工食品への抗酸化剂の 添加を削減でき, 消費者の食の安全・安心のニーズに 対応できる.

以上のことから著者らは，トウモロコシデンプンに 酒石酸を添加して焼成することで糖質系食品素材に $\mathrm{DPPH}$ ラジカル消去活性, ORAC(oxygen radical absorbance capacity) 法を指標とした抗酸化能を付与で きることを明らかとし，ANOX糖（抗酸化糖）と命名し た [14]．ANOX糖の製法で得られる糖質系食品素材の特 性を検討したところ，pH12 溶液で処理しても抗酸化活 性が約 60 \% 維持でき，デンプン分解酵素作用の活性阻 害を有していた。また，メラノイジンは，脱色しても 脱色前と同程度の抗酸化活性をもつことが報告されて おり，ほとんど褐変していない酒石酸 ANOX糖で抗酸 化活性が確認されていることと類似している．以上の ように，メラノイジンの特性と ANOX 糖の特性が類似 していることから ANOX糖には，メラノイジン様の物 質が含まれていると考察している [14-15].

本研究では，糖質系食品素材としてトウモロコシデ ンプン，米粉を用いて抗酸化能だけでなく色調，味も 食品原料として利用できる抗酸化能をもつ糖質系食品 素材が製造可能な最適条件（酒石酸濃度，焼成温度 · 時間）を明らかにすることを目的とした。

\section{2. 実験}

\section{1 実験材料}

\subsection{1 糖質系食品素材}

米は，平成 20 年産の石川県農業総合研究センターで 栽培したコシヒカリの玄米扎よび $90 \%$ 精米の製粉，お よび米デンプン（ファインスノウ：上越スターチ社製） を用いた。 トウモロコシは，コーングリッツ（フラワー イエローNo. 7 ：サニーメイズ社製)，トウモロコシ デンプン（日食コーンスターチ $\mathrm{W}$ ：日本食品化工社製） を用いた。

\subsection{2 酒石酸}

$\mathrm{L}(+)$ 一酒石酸（食品添加物用：キシダ化学社製）を 用いた。

\section{2 実験方法}

\subsubsection{ANOX 糖の調整法}

一定量の酒石酸（0, 0.1, 0.5, 1, 5, 10, $20 \mathrm{~g} ）$ を $30 \mathrm{ml}$ の蒸留水で溶解した酒石酸溶液を糖質系食品素材粉末 $100 \mathrm{~g}$ に混合した粉末を用意し，この粉末をアルミ製の トレーに $1 \mathrm{~cm}$ 厚に敷き詰めた。設定温度（80〜 $\left.200^{\circ} \mathrm{C}\right)$ に到達した通風乾燥機にトレーを入れ，焙焼時 間 $(0,30,45,60,180$ 分) ごとに取り出した。焙焼後の ANOX糖をミルで粉砕して，目開き $420 \mu \mathrm{m}$ の篩を通し た粉を ANOX 糖とした。

対照サンプルとして, 1)各種糖質系食品素材 (玄米粉, 精米粉，米デンプン，コーングリッッ，トウモロコシ デンプン), (2)各種糖質系食品素材 $100 \mathrm{~g}$ と酒石酸溶液 (20 g/30 ml 蒸留水) を混合して凍結乾燥した粉末, (3) 各種糖質系食品素材 $100 \mathrm{~g}$ と蒸留水 $30 \mathrm{ml}$ を混合して $170^{\circ} \mathrm{C}$ で 1 時間焙焼した粉末を試験に供した。

また，ANOX糖は，(4)とした。

\subsection{2 抗酸化能測定法}

ANOX 糖 $100 \mathrm{mg}$ に $0.1 \mathrm{M}$ 酢酸緩衝液 $(\mathrm{pH}=5.0) 50 \%$ 工 タノール液を $9.6 \mathrm{ml}$ 加え，試験管ミキサで 1 分間振と うした後に，遠心分離 $(1006 \times \mathrm{g}, 5$ 分間）し上澄みを サンプル液とした.

サンプル液 $2.4 \mathrm{ml}$ に DPPH 液を $0.1 \mathrm{ml}$ 添加して，摚 拌した. DPPH 液を添加してから 10 分後に吸光光度計 (UV-1700：島津製作所社製）で $520 \mathrm{~nm}$ の吸光度を測定 した.

活性は試料 1 グラム当たりの trolox（ $\mu \mathrm{mol）}$ 相当量 として算出した。

\subsubsection{ANOX 糖の色調測定法}

ANOX 糖粉末を粉末用丸セルに敷き詰め，丸セルを専 用のブラックケースにセットして分光色彩計 (SD-5000：日本電色工業社製）を用いて反射測定で $\mathrm{L}$ 值を測定した。

\subsection{4 酸味の測定法}

$50 \mathrm{ml}$ 容のプラスチックチューブに ANOX 糖 $45 \mathrm{mg}$ を 測り取り，蒸留水 $45 \mathrm{ml}$ に加えて試験管ミキサで 1 分 間振とうした後に，遠心分離 $(1006 \times \mathrm{g}, 5$ 分間）し上 澄みをサンプル液とした。味覚認識装置（SA402B：イ ンテリジェントセンサーテクノロジー社製）を用いて 酸味を測定した。なお，酸味度測定值は，蒸留水の值 を 0 とした。酸味度は，1 以上になると人が舌で味を 感じる值となり，酸味度が 1 違うと人の舌で違いがわ 
かる差である.

\section{3. 結果および考察}

\subsection{ANOX 糖製造法による糖質系食品素材への抗酸化 性付与の有効性}

ANOX 糖製造法で用いる糖質系食品素材に，酒石酸溶 液を混合した後に焙焼する工程の有効性について検討 を行った。

各種処理を行った糖質系食品素材の抗酸化能を測定 した結果は，Fig. 1 に示すと打り，(1)の試験区である糖 質系食品素材のみでも米の素材では，玄米 $(1.89 \mu \mathrm{mol}$ trolox $/ \mathrm{g})>$ 精米 $(0.45 \mu \mathrm{mol}$ trolox $/ \mathrm{g})>$ 米デンプン $(0.07 \mu \mathrm{mol}$ trolox $/ \mathrm{g})$ ，トウモロコシの素材では，コー ングリッツ $(1.13 \mu \mathrm{mol}$ trolox/g) >トゥモロコシデン プン $(0.14 \mu \mathrm{mol}$ trolox/g)の順で抗酸化能が強いが, 最も強い玄米でも trolox 相当量で $1.89 \mu \mathrm{mol}$ trolox $/ \mathrm{g}$ と通常の食品の抗酸化剛として利用されるビタミン C やEに比べ非常に弱かった。また，(2)の試験区である 糖質系食品素材に酒石酸溶液を混合して凍結乾燥した 場合は, 玄米 $(2.26 \mu \mathrm{mol}$ trolox $/ \mathrm{g})>$ 精米 $(0.66 \mu \mathrm{mol}$ trolox $/ \mathrm{g})$ >米デンプン $(0.16 \mu \mathrm{mol}$ trolox $/ \mathrm{g})$, トゥモ ロコシの素材では，コーングリッツ $(1.06 \mu \mathrm{mol}$ trolox/ g) > トゥモロコシデンプン (0.17 $\mu \mathrm{mol}$ trolox/g) の順 で抗酸化能が強く，米の素材では，(1)の試験区に比心゙ 約 1.5 倍抗酸化能が強まったが，トウモロコシの素材で は，ほとんど変化がなかった，次に，(3)の試験区であ る糖質系食品素材に蒸留水 $(15 \mathrm{ml})$ を混合して $170^{\circ} \mathrm{C} て ゙$ 1 時間焙焼した場合は，玄米 $(1.80 \mu \mathrm{mol}$ trolox $/ \mathrm{g})>$

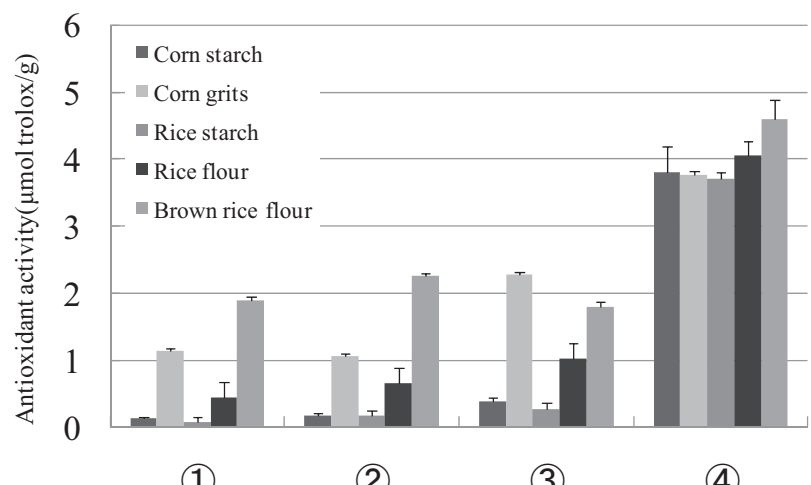

(1)

(2)

(4)

Fig. 1 Imparting antioxidant activity in carbohydrate-based food ingredients by various processes. (1) Carbohydrate-based food ingredient. (2) Carbohydrate-based food ingredient $100 \mathrm{~g}$, tartaric acid $20 \mathrm{~g}$, and distilled water $30 \mathrm{ml}$ were mixed and freezedried. (3) Carbohydrate-based food ingredient $100 \mathrm{~g}$ and distilled water $30 \mathrm{ml}$ were mixed and roasted at $170^{\circ} \mathrm{C}$ for 60 minutes. (4) Carbohydrate-based food ingredient $100 \mathrm{~g}$, tartaric acid $20 \mathrm{~g}$, and distilled water $30 \mathrm{ml}$ were mixed and roasted at $170^{\circ} \mathrm{C}$ for 60 minutes.
精米 $(1.03 \mu \mathrm{mol}$ trolox $/ \mathrm{g})$ >米デンプン $(0.27 \mu \mathrm{mol}$ trolox/g)，トゥモロコシの素材では，コーングリッッ (2.27 $\mu \mathrm{mol}$ trolox/g) >トゥモロコシデンプン $(0.39$ $\mu \mathrm{mol}$ trolox/g)の順で抗酸化能が強かった。值とし ては，コーングリッッが最も強いが，(1)の試験区に比 べて抗酸化能が向上したのは，米デンプンの 3.8 倍で あった，最後に，(4)の試験区である ANOX糖製造法で 調製した場合は，玄米 $(4.57 \mu \mathrm{mol}$ trolox $/ \mathrm{g})>$ 精米 (4.06 $\mu \mathrm{mol}$ trolox $/ \mathrm{g})>$ 米デンプン $(3.72 \mu \mathrm{mol}$ trolox/g)，トウモロコシの素材では，卜ウモロコシデ ンプン $(3.80 \mu \mathrm{mol}$ trolox/g) >コーングリッッ (3.72 $\mu \mathrm{mol}$ trolox/g)の順で抗酸化能が強く, どの糖質系 食品素材に打いても最も抗酸化能が高かった.

さらに，我々は，酒石酸のみを焼成した場合には， 抗酸化能が全く認められないことを確認している [14].

以上の結果より, 糖質系食品素材に抗酸化能を付与 するのに最も効果的なのは，ANOX糖製造法であること が明らかとなった。

しかし，糖質系食品素材の色調は，Fig. 2 に示すよう にANOX糖製造法を用いることで全ての糖質系食品素 材に打いて明度が低下して色調が悪くなった。明度の 低下の程度は，米デンプンやトゥモロコシデンプンで 少なく，玄米粉，精米粉打よびトゥモロコシ粉で顕著 であることから，タンパク質や脂質などの成分の影響 による変色が原因であると考えられる。

\section{2 各種糖質系食品素材の焙焼温度による抗酸化能付 与の消長}

ANOX 糖製造法により，糖質系食品素材に抗酸化能が 効率よく付与される事が明らかとなったので，焙焼温度 による抗酸化能の付与効果を検討した。 すなわち，酒石 酸の添加量 $(20 \mathrm{~g})$ と焙焼時間（1 時間）を一定にして,

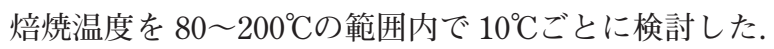

その結果, Fig. 3 に示すと打り, 抗酸化能は, $150^{\circ} \mathrm{C}$ まではほとんど抗酸化能が付与されなかったが， $160^{\circ} \mathrm{C}$

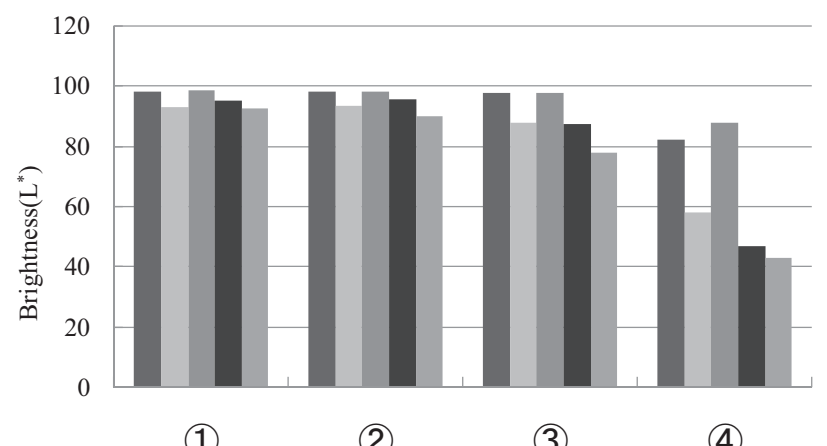

(1)

(2)

(3)

(4)

Fig. 2 Brightness changes in carbohydrate-based food ingredients by various processes. Symbols and numbering are as described in Fig. 1. 
から抗酸化能が付与されるようになり， $170^{\circ} \mathrm{C}$ 以上の焙 焼温度で全ての糖質系食品素材に打いて，付与される 抗酸化能が急激に向上した。

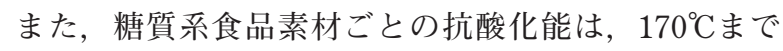
は，玄米粉>精米粉>コーングリッッ>トウモロコシ デンプン>米デンプンの順であったが， $180^{\circ} \mathrm{C}$ かは,

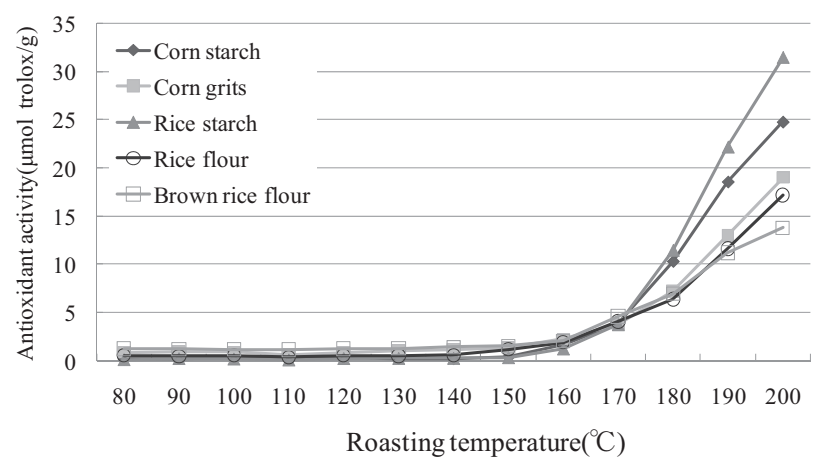

Fig. 3 Effect of different roasting temperatures on antioxidant activity of ANOX sugar. ANOX sugar: Carbohydrate-based food ingredient $100 \mathrm{~g}$, tartaric acid $20 \mathrm{~g}$, and distilled water $30 \mathrm{ml}$ were mixed and roasted at each temperature for 60 minutes.
米デンプン，トゥモロコシデンプンの抗酸化能が急激

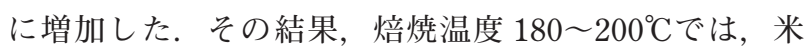
デンプン>トウモロコシデンプン>コーングリッッ> 精米粉>玄米粉の順で抗酸化能が高く, 最も抗酸化能 が高い焙焼温度 $200^{\circ} \mathrm{C}$ の米デンプンでは， $31.48 \mu \mathrm{mol}$ trolox/gであった.

以上の結果より，糖質系食品素材への抗酸化能付与 については，焙焼温度が高いほど付与できる抗酸化能 が向上することが確認できた。ただし，焙焼温度が $200^{\circ} \mathrm{C} よ り$ 高いと炭化が進み食品素材として不適切であ るだけでなく，抗酸化能も下落した.

\section{3 抗酸化能の高付加条件の検討}

ANOX 糖製造法に打いて，糖質系食品素材に付与する 抗酸化能の程度が異なることが確認できたため，抗酸 化能を付与しやすく，価格が安いトウモロコシデンプ ンを糖質系食品素材として選択して ANOX糖製造法に 打ける酒石酸添加量（0～20 g)，焙焼温度（170～ $\left.200^{\circ} \mathrm{C}\right)$ ，焙焼時間（0１80 分）を組み合わせて最も抗 酸化能を付与できる ANOX糖製造法の条件を検討した.

その結果，Fig. 4 に示すと打り，焙焼温度が 170〜

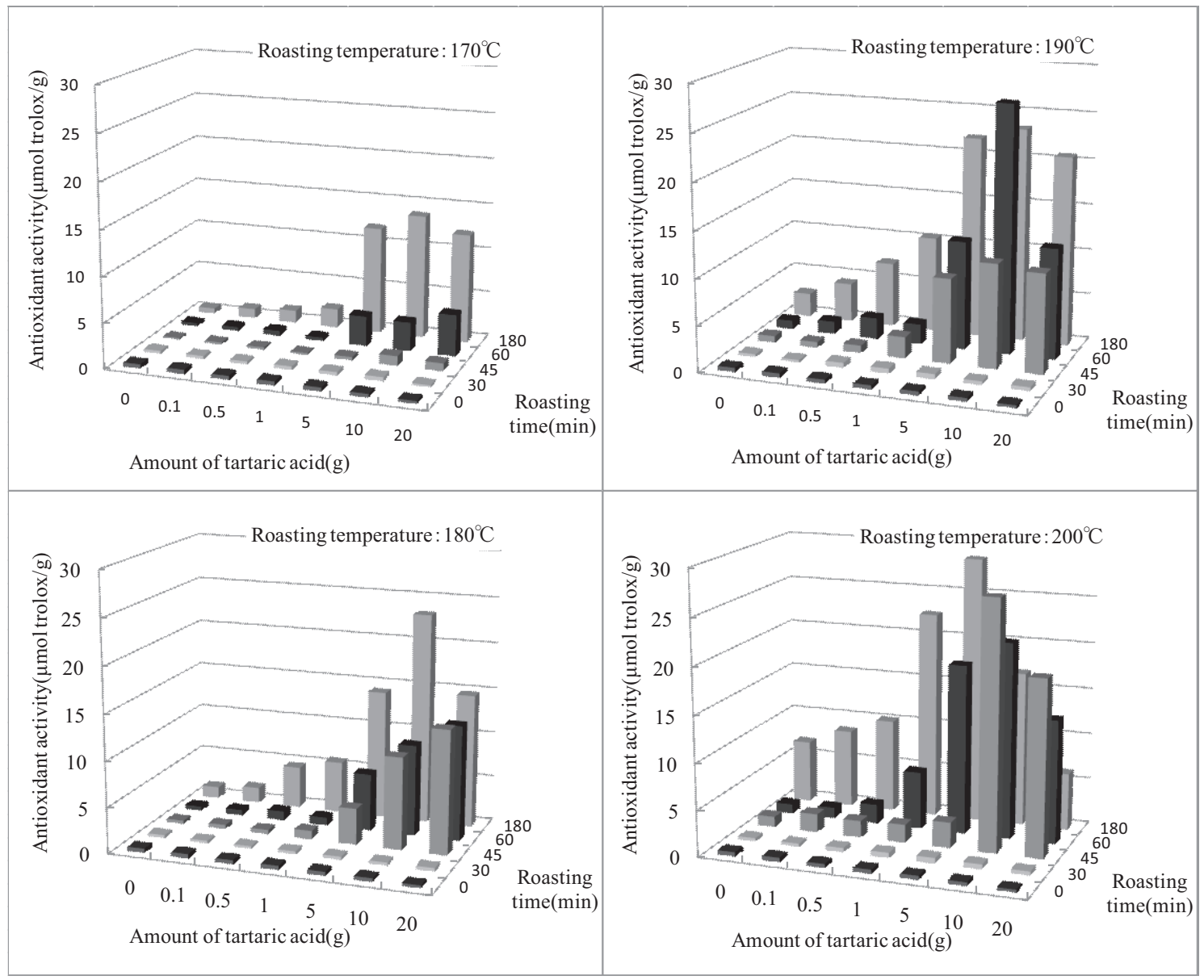

Fig.4 Antioxdant activity at different processing conditions of the ANOX-sugar. Roasting time(mini.): $\square 0 \quad \square 30$ $\square 4 \square 60 \square 180$ 


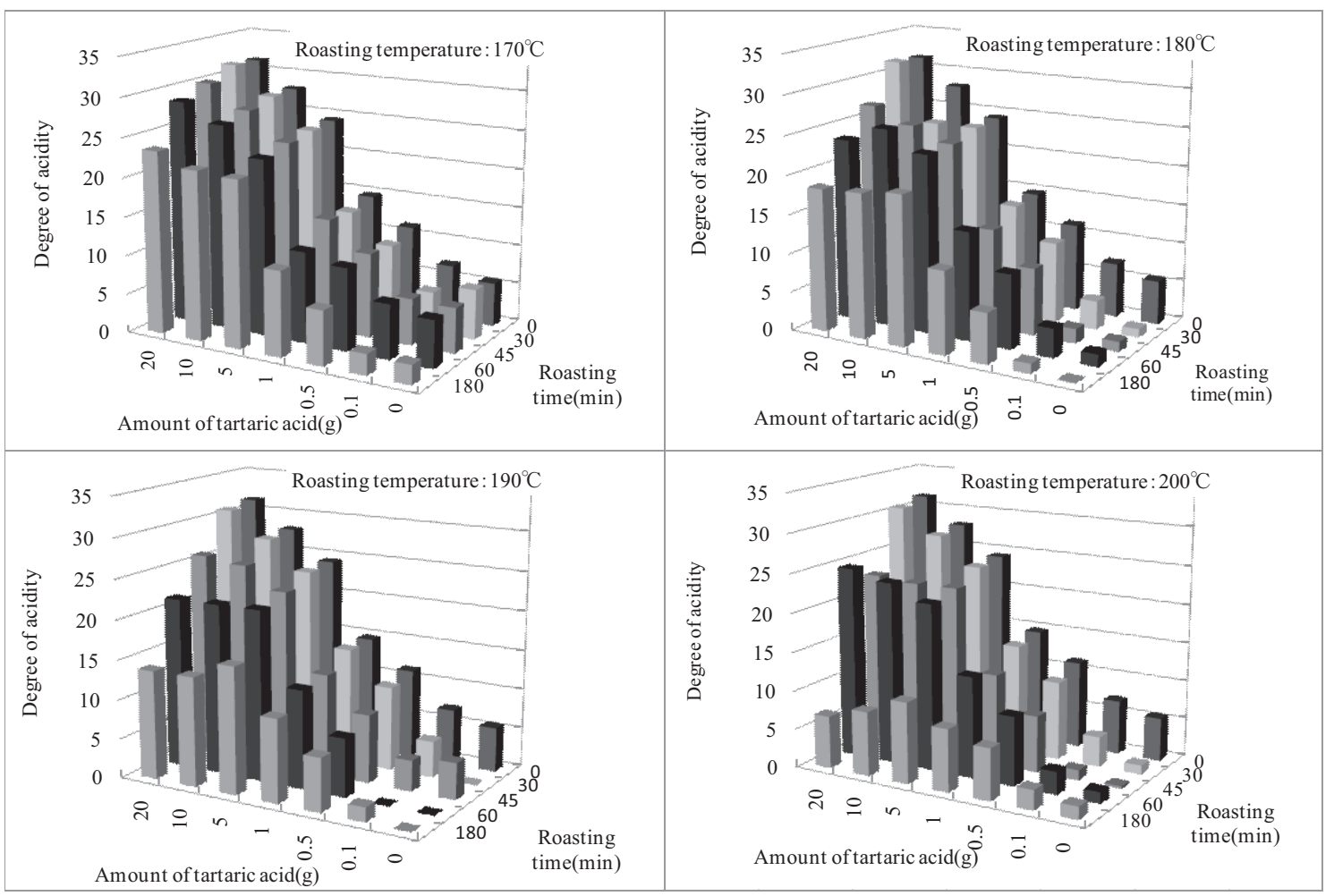

Fig.5 Acidity at different processing conditions of the ANOX-sugar. Roasting time(mini.): $\begin{gathered}0 \quad \square \\ 0\end{gathered}$ 180

$180^{\circ} \mathrm{C}$ までは，酒石酸添加量に関わらず焙焼時間が長い

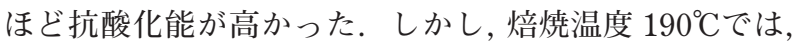
酒石酸添加量 $10 \mathrm{~g}$ に限って，焙焼時間 60 分が最も抗 酸化能が高く，焙焼温度 $200{ }^{\circ} \mathrm{C}$ では，酒石酸添加量 10 〜20 g で焙焼時間 45 分が最も抗酸化能が高かった。さ らに，焙焼温度が $170 \sim 180^{\circ} \mathrm{C}$ では，焙焼時間 180 分，

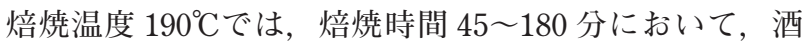
石酸添加量 $10 \mathrm{~g}$ が最も抗酸化能が高かった。焙焼温度 $200^{\circ} \mathrm{C}$ で，焙焼時間 45〜 60 分で酒石酸添加量 $10 \mathrm{~g}$ ，焙 焼時間 180 分で酒石酸添加量 $5 \mathrm{~g}$ が最も抗酸化能が高 かった。すなわち，酒石酸添加量には，最も抗酸化能を 付与できる適正量が存在することが認められた (Fig. 4).

全ての製造条件の内で抗酸化能が $25 \mu \mathrm{mol}$ trolox $/ \mathrm{g}$ 以上であったのは，次の 3 条件であった。（1）焙焼温 度 $190^{\circ} \mathrm{C}$ ，焙焼時間 60 分，酒石酸添加量 $10 \mathrm{~g}$ で抗酸化 能 $26.93 \mu \mathrm{mol}$ trolox $/ \mathrm{g} ，(2)$ 焙焼温度 $200^{\circ} \mathrm{C}$ ，焙焼時 間 45 分，酒石酸添加量 $10 \mathrm{~g}$ で抗酸化能 $26.83 \mu \mathrm{mol}$

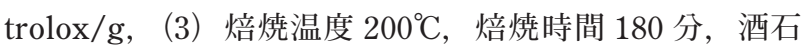
酸添加量 $5 \mathrm{~g}$ で抗酸化能 $28.75 \mu \mathrm{mol}$ trolox/g であっ た。このうち最も高い抗酸化能を付与できたのは，(3) の条件であった。

\section{4 加工原料として適する ANOX 糖製造法の条件解明}

糖質系食品素材にトウモロコシデンプンを用いて,
ANOX 糖製造法の焙焼温度，焙焼時間，酒石酸添加量の 組み合わせにより，糖質系食品素材に付与される抗酸 化能を調整が可能であることを明らかにした。 しかし， 焙焼温度や時間によって ANOX糖の色調が褐変したり，

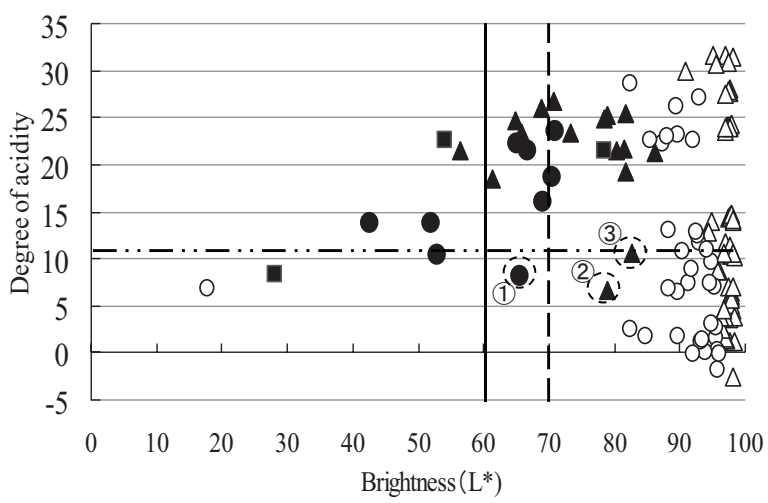

Fig. 6 Correlation between degree of acidity and brightness with different processing conditions ANOX-sugars. Antioxdant activity $(\mu \mathrm{mol}$ trolox $/ \mathrm{g}): \triangle$ Less than $1, \bigcirc$ More than 1 less than 10, $\boldsymbol{\Delta}$ More than 10 less than 15, $\mathbf{\square}$ More than 15 less than 20, More than 20. - - - - - Limit for acidity, : Brightness limit of low quality,

Brightness limit of high quality. $:$ : The process conditions of Anox-sugar can be used as raw for food processing 
酒石酸添加量が増えることで酸味が強くなる。そこで, 各種製造条件で調製したANOX糖の酸味と色調を測定 して，ANOX糖の品質を評価した。

その結果， Fig. 5 に示すように酒石酸添加量が多いほ ぞ酸味度が高い傾向であるが，焙焼温度が高く，焙焼 時間が長いと酒石酸量が多くても酸味度が高くならな い傾向が認められた。この傾向が認められるのは，焙 焼温度 $170^{\circ} \mathrm{C}$ では, 焙焼時間 180 分, $180 \sim 190^{\circ} \mathrm{C}$ では,

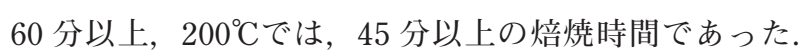
ANOX 糖の色調（明度）は，Fig. 6 に示すように抗酸化 能が $10 \mu \mathrm{mol}$ trolox/g 以下では， 1 製造条件を除いて 全て明度が 80 以上であった。抗酸化能が $10 \mu \mathrm{mol}$ trolox/g 以上 $15 \mu \mathrm{mol}$ trolox $/ \mathrm{g}$ 未満の範囲では, 明度 は 56 83 の範囲であった。さらに，抗酸化能が 15 $\mu \mathrm{mol} t \mathrm{trolox} / \mathrm{g}$ 以上では, 明度は 28〜79 の範囲であっ た。このことから，抗酸化能が高い ANOX糖ほど褐変 の程度が大きいことが認められた。

加工原料として適する ANOX 糖は，原料となる糖質系 食品素材に比べ一定程度抗酸化能が強く, 色調が白に 近く, 酸味が弱い特徴を持つと考えられ, その要件を 満たす製造条件の絞り込みを適正な抗酸化能, 明度打 よび酸味度を定めて Fig. 6 から判断した。

すなわち，抗酸化能は，原料の糖質系食品素材とし て用いているトウモロコシデンプンの抗酸化能が 0.14 $\mu \mathrm{mol}$ trolox/gであることからその 100 倍近い 10 $\mu \mathrm{mol} \mathrm{trolox} / \mathrm{g}$ 以上，明度は，Fig. 7 で示すように褐 変が肉眼で明確に判別できる明度 60 より高い值, 酸味 度は, 共同研究に参画しているメンバーによる官能試 験の結果から, 焙焼温度 $180^{\circ} \mathrm{C}$, 焙焼時間 180 分, 酒石 酸添加量 $1 \mathrm{~g}$ の条件で調製した ANOX 糖の酸味度 10.70 以下と決めた。抗酸化能, 明度, 酸味度の各条件を満 たす ANOX糖製造条件として, (1) $200^{\circ} \mathrm{C} 180$ 分酒石酸 $1 \mathrm{~g}$, (2) $200^{\circ} \mathrm{C} 180$ 分酒石酸 $0.5 \mathrm{~g}$, (3) $190^{\circ} \mathrm{C} 180$ 分酒石酸 $1 \mathrm{~g}$

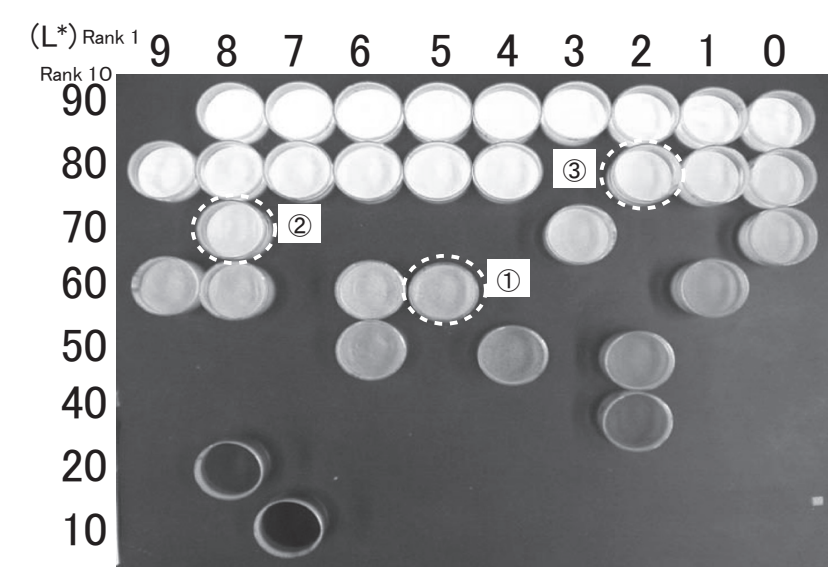

Fig. 7 Brightness at different processing conditions of the ANOX-sugar. : : The process conditions of Anox-sugar can be used as raw for food processing

\section{の 3 条件が該当した。}

それぞれの製造条件によるANOX糖の特徴は，(1)抗酸 化能 $22.46 \mu \mathrm{mol}$ trolox $/ \mathrm{g}$, 明度 65.53 , 酸味度 8.07 , (2)抗酸化能 $10.16 \mu \mathrm{mol}$ trolox $/ \mathrm{g}$, 明度 78.81 , 酸味度 6.68, (3)抗酸化能 $10.47 \mu \mathrm{mol}$ trolox $/ \mathrm{g}$, 明度 82.71 , 酸味度 10.51 であった。

抗酸化能の強さは，(1)が最も強いが，色調が他の二 つに比べ褐変が進んでいるため, 利用範囲が限定され る。それに比べ(2)，(3)の製造条件は，抗酸化能が(1)に 比べ半分以下になるが, 色調や酸味度が良好であり加 工原料として利用範囲が広いと考元られる.

以上の結果より，(1)〜 (3)の製造条件が，加工原料と して適する ANOX糖製造法の条件と考えられた。

本研究で開発したANOX糖の食品製造における利用に ついて考察する. ANOX糖は，米粉打よびデンプンなど の糖質系食品素材を主原料としているため，元の糊化 特性をラピッドビスコアナライザで評価したところ, 加熱による粘度変化がほとんど観察されなかった。こ れは，原料の米粉やデンプンとは全く異なる糊化特性 であり，デキストリンなどのデンプン加水分解物に近 いものであった。この結果より, ANOX糖の主原料であ る糖質系食品素材中のデンプンは，加水分解打よび水 不溶化したと考えられた [15].

このような ANOX 糖の特性は, 加工食品に添加した場 合にデンプン糊化による粘度上昇を示さないので幅広 い用途に利用可能な，抗酸化剂の代替となる抗酸化能 をもつ糖質系食品素材と考えられる。 その用途として は， ドーナッツなどの油脂含量が高い加工食品の自動 酸化抑制や防災用乾パンなどの貯蔵用食品に打ける自 動酸化抑制などが期待できる.

具体的にイーストドーナッツへの利用を想定すると， 一般的にイーストドーナッ $100 \mathrm{~g}$ には, 抗酸化能をも

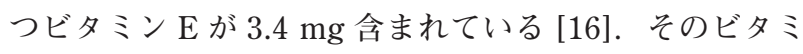
ン $\mathrm{E}$ を抗酸化活性が最も強い $\alpha$-トコフェロールの抗酸 化能 $(460 \mu \mathrm{mol}$ trolox/g) に換算するとイーストドー ナッ $100 \mathrm{~g}$ に添加されたビタミン $\mathrm{E}$ の抗酸化能は, 約 $1.56 \mu \mathrm{mol}$ trolox $/ \mathrm{g}$ となる [17-18]. これを本研究で 開発した製造条件で最も抗酸化能が低い(2)の ANOX 糖 (抗酸化能 $10.16 \mu \mathrm{mol}$ trolox $/ \mathrm{g}$ ) に置き換えて添加し た場合は，イーストドーナツ $100 \mathrm{~g}$ に約 $0.15 \mathrm{~g}$ の ANOX 糖を添加すればよいことになる。この程度の添加であ れば，ドーナッツの食感，色，味に影響を及ぼすこと なく製造が可能と考えられる.

このようなことから，現在，我々は，石川県産業創 出支援機構の活性化ファンド予算を受けて, 防災用乾 パン企業と共同で簡易包装でも長期貯蔵可能な米粉乾 パンの商品開発研究を米粉 ANOX 糖添加により検討し ている. 


\section{4. 謝}

辞

本研究は, 平成 20 年度（財）すかいらーくフードサイ エンス研究所学術研究助成により行われたものである.

\section{引用 文 献}

1) R. Ando; "New processing and utilization technologies and characteristics of corn (Konsutachi no tokusei to shinkakou,riyo gijyutu)" Gekkan fudokemikaru, Tokyo, Japan, 2007, pp. 19-22.

2) K. Nishikawa; "Science of Functional Foods" (in Japanese) In Tech Information s. c. Ltd., Tokyo, Japan, 2008, pp.505-508.

3) A. Kubo, G. Akdogan, M. Nakaya, A. Shojo, S. Suzuki, H. Satoh, S. Kitamura; Structuer, Physical, and Digestive Properties of Starch from wx ae Double-Mutant Rice. J. Agric. Food Chem., 58, 4463-4469(2010).

4) R. Hirose; "For its use and functionality of polyphenols and vitamin (Poripyenoru oyobi a Bitamin no Kinosei to sonoriyo nitsuite)", Japan food industry center, Tokyo, Japan, 2006, pp.33-56.

5) T. Okada, N. Yamaguchi; Antioxidative Effect and Pharmacology of Oryzanol(in Japanese). J. Jpn. Oil Chem. Soc., 33, 305-310 (1983).

6) H. Taniguchi;Ferulc acid produced from rice bran and its application to cancer chemopreventive agents (in Japanese). Breeding Research, 4, 24-27 (2002).

7) H. Tozawa; “Corn (Tomorokoshi)" Nobunkyo, Tokyo, Japan, 2005, pp.345-353.

8) H. Saneoka, N. Honda; Changes in Phytic Acid-P and Phosphorus Compounds with the Maturity of Maize Grain. Grassland Science, 49, 425-529 (2003).

9) H. Tozawa; "Corn (Tomorokoshi)" Nobunkyo, Tokyo, Japan, 2005, pp. 146-147.

10) T. Itani, H. Tatemoto, M. Okamoto, K. Fujii, N. Muto; A Comparative Study on Antioxidative Activity and Polyphenol Content of Colored Kernel Rice(in Japanese). J. Jpn. Soc. Food Sci. Technol., 49, 540-543 (2002).

11) K. Higashi-Okai, E. Ishida, Y. Nakamura, S. Fujiwara, Y. Okai; Potent Antioxidant and Radical-Scavenging Activities of Traditional Japanese Cereal Grains. J. UOEH, 30, 375-389 (2008).
12) Soda Aromatic Co., Ltd.; “Antioxidant substance (Kosankazai)”, (in Japanese), Japanese Patent Disclosure P2002-161042A (2002).

13) H. Shimabayashi, H. Tanaka; Natural Antioxidant Preparation "SANMELIN Series" (in Japanese). Foods \& Food Ingredients J. Jpn., 216, 77-83 (2011)

14) S. Miwa, M. Nakamura, M. Okuno, H. Miyazaki, J. Watanabe, Y. Ishikawa(Takano), M. Miura, N. Takase, S. Hayakawa, S. Kobayashi; Production of starch having antioxidative activity by baking starch with organic acids, Biosci. Biotechnol. Biochem., in press.

15) M. Miura: Evaluation of physicochemical properties of saccharide food ingredients (ANOX sugar) (in Japanese). Annual Report of Study for Food, 22, 127-136 (2009)

16) Y. Kagawa; "Standard Tables of Food Composition in Japan 2004 (Gotei Syokuhin Seibun Hyou 2004)” , Jyoshieiyo daigaku syuppanbu, Tokyo, Japan, 2004, p.223.

17) Y. Kagawa; "Standard Tables of Food Composition in Japan 2004 (Gotei Syokuhin Seibun Hyou 2004)”, Jyoshieiyo daigaku syuppanbu, Tokyo, Japan, 2004, p.18.

18) Japan Food Research Laboratories; Comparison of antioxidative activities of various foods (in Japanese). JFRL News, 32, 1-4(2003).

\section{和文 要 旨}

加工食品は, 加熱工程や保存中に酸敗を受けやすい ので抗酸化剤が使用される。しかし，天然物由来の抗 酸化剂であっても利便性や安全性を完全に満足してい ない，そこで，加工原料として広く利用されている糖 質系食品素材に酒石酸を添加して加熱処理だけで簡便 に抗酸化能を付与できる技術を開発し，ANOX糖と命名 した. ANOX糖を製造すると糖質系食品素材の抗酸化能 が向上すると同時に，素材の褐変や酸味など食品素材 として不適な特徴も付与される。本研究では，これら の加工原料として不適な特徵をできるだけ押さえて抗 酸化能を向上させる ANOX糖製造条件を検討した。そ の結果, 特性として抗酸化能が $10 \mu \mathrm{mol}$ trolox/g以上, 素材色調が明度 60 以上，酸味度が 10.7 以下の ANOX 糖 が得られる製造条件として, (1) $200^{\circ} \mathrm{C}, 180$ 分酒石酸 $1 \mathrm{~g}$, (2) $200^{\circ} \mathrm{C}, 180$ 分酒石酸 $0.5 \mathrm{~g}$, (3) $190^{\circ} \mathrm{C}, 180$ 分酒石酸 $1 \mathrm{~g}$ の 3 条件を見出した. 